\title{
PENERAPAN MODEL PROBLEM BASED LEARNING BERBANTUAN GEOGEBRA UNTUK MENINGKATKAN KEMAMPUAN BERPIKIR KREATIF MATEMATIS SISWA SMA NEGERI 1 MUARA BATU
}

\author{
Meiliza Aminy ${ }^{1}$, Herizal $^{2}$, Wulandari ${ }^{3}$ \\ ${ }^{1,2,3}$ Program Studi Pendidikan Matematika, Universitas Malikussaleh, Aceh Utara, Indonesia \\ meilizaminy@gmail.com ${ }^{1}$ \\ herizal_mathedu@unimal.ac.id \\ wulandari@unimal.ac.id ${ }^{3 *}$
}

\begin{abstract}
Abstrak
Kurangnya kegigihan dalam penyelesaian masalah membuat siswa terlihat sukar menyelesaikan masalah yang berbeda, hal ini menyebabkan rendahnya kemampuan berpikir kreatif matematis siswa. Untuk itu penggunaan model Problem Based Learning (PBL) berbantuan GeoGebra diharapkan meningkatkan kemampuan berpikir kreatif matematis siswa. Adapun penelitian ini bertujuan untuk melihat peningkatan kemampuan berpikir kreatif matematis siswa yang diajarkan melalui model Problem Based Learning (PBL) berbantuan GeoGebra lebih baik daripada siswa yang diajarkan melalui pendekatan saintifik di SMA Negeri 1 Muara Batu. Penelitian ini merupakan penelitian quasi experimental design dengan menggunakan desain penelitian nonequivalent control group design. Populasi dalam penelitian ini adalah siswa kelas XI SMA Negeri 1 Muara Batu tahun ajaran 2019/2020 dan sampel penelitian adalah siswa kelas XI MIPA 2 sebagai kelas eksperimen dan siswa kelas XI MIPA 3 sebagai kelas kontrol yang dipilih secara purposive sampling. Data diperoleh dari hasil tes instrumen kemampuan berpikir kreatif matematis siswa berupa tes pretest dan postest serta dianalisis uji normalitas, homogenitas, dan uji hipotesis berbantuan software SPSS 25. Hasil penelitian menunjukan bahwa peningkatan kemampuan berpikir kreatif matematis siswa yang menggunakan model pembelajaran Problem Based Learning berbantuan GeoGebra lebih baik dari pada siswa yang belajar menggunakan pendekatan saintifik di SMA Negeri 1 Muara Batu.
\end{abstract}

Kata kunci: Geogebra, Kemampuan Berpikir Kreatif Matematis, Problem Based Learning (PBL)

\section{PENDAHULUAN}

Pada era 4.0, perkembangan teknologi dan ilmu pengetahuan memungkinkan semua pihak untuk mendapatkan informasi secara melimpah, cepat dan mudah dari berbagai sumber dan segala penjuru dunia. Oleh karena itu, di era sekarang manusia dituntut untuk memiliki kemampuan dalam memperoleh, menyeleksi, mengelola informasi itu agar dapat dimanfaatkan dalam kehidupan yang dinamis, penuh tantangan, dan kompetitif. Hal itu menuntut dimilikinya kemampuan berpikir kreatif.

Terkait hal tersebut, upaya mengembangkan kemampuan dan keterampilan dalam kegiatan pembelajaran telah dilakukan dengan peningkatan kualitas pembelajaran baik dari 


\section{Vol 1, Nomor 1, Mei 2021}

segi penguasaan materi, penggunaan metode, penggunaan media maupun pengelolaan kelas yang kondusif. Sebagaimana diatur dalam Permendiknas Nomor 41 Tahun 2007 tentang Standar Proses bahwa proses pembelajaran pada setiap satuan dasar dan menengah harus interaktif, inspiratif, menyenangkan, menantang, dan memotivasi peserta didik untuk berpartisipasi aktif, serta memberikan ruang yang cukup bagi prakarsa, kreativitas, dan kemandirian sesuai dengan bakat, minat, dan perkembangan fisik serta psikologis peserta didik.

Berdasarkan observasi di SMA Negeri 1 Muara Batu, didapat bahwa kemampuan berpikir kreatif siswa rendah. hal ini dapat dilihat dari gejala-gejala berikut: 1) Siswa masih kurang memenuhi indikator keluwesan seperti merasa sukar mengerjakan soal yang berbeda dari bentuk contoh yang diberikan oleh guru. 2) Dalam mengerjakan soal, siswa masih terfokus pada satu rumus dan belum bisa mencari dan menyelesaikan soal dengan cara alternatif yang lain selain dari contoh yang diberikan oleh guru, hal ini dilihat masih kurangnya siswa dalam indikator keaslian. 3) Dalam mengerjakan soal, sebagian siswa masih kurang menerapkan menggunakan langkah-langkah yang terperinci, dalam hal ini siswa masih kurang dalam indikator elaboration. 4) Kurangnya keinginan tahu siswa dalam belajar terutama belajar matematika. 5) Kurangnya kegigihan siswa dalam mengerjakan soal. Dengan melihat permasalahan yang ditemui di lapangan, maka tampaknya siswa menjadi kurang aktif dalam pembelajaran sehingga perkembangan pola pikir anak menjadi terbelenggu dan dapat menurunkan daya kreatifitas siswa.

Keunggulan Problem Based Learning dalam pengembangan kemampuan berpikir kreatif matematis berbantuan GeoGebra didukung adanya penelitian sebelumnya yang dilakukan oleh (Selvy, 2018) bahwa peningkatan kemampuan berpikir kreatif matematis dan motivasi siswa yang memperoleh pembelajaran dengan model PBL berbantuan software GeoGebra lebih baik daripada siswa yang memperoleh pembelajaran model PBL tanpa bantuan software GeoGebra. Penelitian yang dilakukan oleh (I Wayan Eka Aryasuta, I Nengah Suparta, 2014) bahwa terdapat perbedaan yang signifikan pada prestasi belajar matematika siswa yang mengikuti pembelajaran model PBL dengan media pembelajaran berbantuan GeoGebra dan prestasi belajar matematika siswa yang mengikuti pembelajaran model PBL. Penelitian yang dilakukan oleh (Rahmadani , 2017) bahwa Peningkatan kemampuan berpikir kreatif matematis siswa yang memperoleh pembelajaran dengan strategi Brain-based learning berbantuan GeoGebra lebih baik daripada peningkatan kemampuan berpikir kreatif matematis siswa yang memperoleh pembelajaran dengan strategi ekspositori.

Menurut (Nadeem et al., 2012), berpikir kreatif matematis adalah cara baru dalam melihat dan mengerjakan sesuatu yang memuat 4 aspek antara lain, fluency (kefasihan), flexybility (keluwesan), originality (keaslian), dan elaboration (keterincian). Dari berbagai definisi dapat disimpulkan bentuk perilaku dari berpikir kreatif sebagi berikut.

\section{Tabel 1. Indikator Kemampuan Berpikir Kreatif}

\section{Indikator Kemampuan Berpikir Kreatif}

Fluency (Kefasihan)

\section{Perilaku Kemampuan Berpikir Kreatif}

- Kemampuan menghasilkan banyak gagasan/jawaban.

- memberikan banyak cara atau saran untuk melakukan berbagai hal.

- memikirkan lebih dari satu jawaban. 
Vol 1, Nomor 1, Mei 2021

\begin{tabular}{cl}
\hline Elaboration & Kemampuan memiliki gagasan yang luas. \\
(Keterincian) & - Kemampuan merinci detail-detail tertentu. \\
& - Mampu menghasilkan gagasan, jawaban atau pernyataan \\
Flexybility (Keluwesan) & dari sudut pandang yang berbeda-beda. \\
& - Kemampuan memberikan arah pemikiran yang berbeda. \\
& - Banyaknya variasi kemampuan memberikan jawaban yang \\
Originality (Keaslian) & tidak lazim. \\
& - Banyaknya variasi kemampuan memberikan arah pemikiran \\
& yang berbeda.
\end{tabular}

Problem Based Learning adalah seperangkat model mengajar yang menggunakan masalah sebagai fokus untuk mengembangkan keterampilan pemecahan masalah, materi, dan pengaturan diri (Eggen \& Kauchak, 2012). Sedangkan menurut (Supinah \& Sutanti, 2010) mengemukakan bahwa Problem Based Learning sebagai pendekatan pembelajaran yang diawali dengan pemberian masalah kepada siswa dimana masalah tersebut diawali dengan pemberian masalah kepada siswa dimana masalah tersebut dialami atau merupakan pengalaman sehari-hari siswa.

Menurut (Arends, 2013) adapun sintaks untuk model Problem Based Learning sebagai berikut:

Tabel 2. Sintaks Problem Based Learning menurut Arends

Tahap 1

\section{Tahap}

Mengarahkan siswa kepada masalah

Tahap 2

Mempersiapkan siswa untuk belajar

Tahap 3

Membantu mandiri dan kelompok

Tahap 4

Mengembangkan menyajikan artefak (laporan tertulis) dan benda panjang (presentasi)

Tahap 5

Menganalisis

mengevaluasi

pemecahan permasalahan

\section{Perilaku Guru}

Guru meninjau ulang tujuan pembelajaran, menjabarkan persyaratan logistik yang penting dan memotivasi siswa untuk terlibat dalam kegiatan pemecahan masalah.

Guru membantu siswa mendefinisikan dan menyusun tugastugas belajar yang terkait dengan permasalahan.

Guru mendorong siswa untuk mengumpulkan informasi yang sesuai, mengadakan eksperimen, dan mencari penjelasan dan solusi.

Guru membantu siswa dalam merencanakan dan mempersiapkan artefak yang sesuai seperti laporan, video dan model, serta membantu mereka membagikan pekerjaan mereka dengan orang lain.

Guru membantu siswa untuk merefleksikan penyelidikan dan mereka dan proses yang mereka gunakan.

\section{METODE}

\section{Jenis Penelitian}




\section{Vol 1, Nomor 1, Mei 2021}

Penelitian ini menggunakan pendekatan kuantitatif karena data yang diperoleh dari hasil penelitian berupa angka-angka dan analisis menggunakan rumus statistik. Adapun jenis penelitian yang dipergunakan adalah penelitian eksperimen semu (quasi eksperiment). (Sugiyono, 2010) mendefinisikan bahwa penelitian eksperimen semu yaitu penelitian yang mempunyai kelompok kontrol tetapi tidak dapat berfungsi sepenuhnya untuk mengontrol variabel-variabel luar yang mempengaruhi pelaksanaan eksperimen.

\section{Waktu dan Tempat Penelitian}

Lokasi penelitian ini dilaksanakan di SMA Negeri 1 Muara Batu yang berlokasi di Jl. Pendidikan No. 5 Krueng Mane, Kecamatan Muara Batu, Kabupaten Aceh Utara. Sedangkan waktu penelitian dilaksanakan pada semester genap tahun ajaran 2019/2020.

\section{Populasi/ Sampel}

Populasi dari penelitian ini adalah seluruh siswa kelas XI SMA Negeri 1 Muara Batu, yang jumlah kelasnya 9. Yang menjadi sampel adalah siswa kelas XI MIPA 2 sebagai kelas eksperimen dan siswa kelas XI MIPA 3 sebagai kelas kontrol dengan pertimbangan kelas tersebut homogen atau memiliki kemampuan yang relatif sama dari sisi nilai.

\section{Prosedur}

Penelitian eksperimen ini terdiri dari 3 tahap yaitu, tahap persiapan tahap pelaksanaan dan tahap analisa data. Pada tahap persiapan dilakukan beberapa kegiatan, yaitu: 1) Permohonan izin kepada pihak sekolah SMA Negeri 1 Muara Batu untuk melakukan penelitian; 2) melakukan pra riset dan melakukan wawancara dengan guru matematika; 3) identifikasi masalah; 4) Menyusun perangkat pembelajaran; 5) Menyusun instrumen penelitian; 6) Memvalidasi perangkat pembelajaran dan instrumen penelitian; 7) Merevisi perangkat pembelajaran dan instrumen; 8) Melakukan uji coba soal; 9) Menganalisis data hasil uji coba; 10) Merevisi instrumen penelitian berdasarkan hasil uji coba.

\section{Data, Intrumen, dan Teknik Pengumpulan Data}

Teknik pengumpulan data yang digunakan pada penelitian ini, adalah memberikan tes. Bentuk tes yang digunakan adalah essay, serta dengan menggunakan indikator berpikir kreatif matematis. Tes yang akan disusun, diukur terlebih dahulu tingkat (kriteria) validitas, reliabilitas, daya pembeda dan tingkat kesukaran soal sebelum digunakan dalam pengumpulan data, dengan maksud untuk mendapatkan ketepatan data. Dalam penelitian tes dilakukan dengan:
a. Memberikan tes awal (pretest) untuk mengukur keadaan awal siswa.
b. Setelah materi selesai disampaikan, maka siswa diberi tes akhir (posttest) untuk mengukur kemampuan berpikir kritis matematis siswa setelah diberi perlakuan.

\section{Teknik Analisis Data}

\section{Uji n-Gain}

Untuk menghitung tingkat kemampuan berfikir kreatif matematis siswa, yaitu nilai/skor gain ternormalisasi ( $n$-Gain) yang dihitung dengan rumus meltzer :

Keterangan:

$$
\mathrm{N}-\text { Gain }=\frac{S P S-S P r}{S M I-S P r} \quad \quad \text { (Meltzer, 2002) }
$$


Vol 1, Nomor 1, Mei 2021

SPs : : Skor Postest

SPr : Skor Pretest

SMI : Skor Maksimum

Tabel 3. Skore n-Gain

\begin{tabular}{cc}
\hline Skore $\boldsymbol{n}$-Gain & Kategori \\
$\mathrm{g} \geq 0,7$ & Tinggi \\
$0,7>\mathrm{g} \geq 0,3$ & Sedang \\
$\mathrm{g}<0,3$ & Rendah \\
\hline
\end{tabular}

Sumber : (Hake, 1998)

2. Menguji Normalitas

Uji normalitas ditujukan untuk mengetahui apakah nilai $\mathrm{N}$-gain dari masing-masing kelompok eksperimen berdistribusi normal atau tidak. Uji normalitas digunakan pada penelitian ini menggunakan Shapiro-Wilk karena jumlah sampel kurang dari 100. Hipotesis dalam pengujian normalitas yaitu:

$\mathrm{H}_{0}$ : Data berdistribusi normal

$\mathrm{H}_{\mathrm{a}}$ : Data tidak berdistribusi normal

3. Uji Homogenitas Data

Uji homogenitas ditujukan untuk mengetahui apakah kedua kelas yaitu kelas eksperimen dan kelas kontrol memiliki variansi-variansi yang sama atau tidak. Dengan kata lain apakah kedua kelompok mempunyai variasi pemahaman konsep sama atau tidak. Langkah-langkah untuk mengetahui kehomogenan matriks varians-varians menggunakan adalah uji statistik Levene's Test dengan menggunakan software SPSS 25.

Langkah-langkah mengajukan pengujian :

- Tentukan nilai $\alpha$ (nilai $\alpha$ yang digunakan dalam penelitian ini adalah 0,05 ).

- Mengolah data yang diperoleh dengan menggunakan software SPSS 25.

- Jika nilai pada kolom sig. > 0,05 maka $\mathrm{H}_{0}$ diterima

Adapun rumusan hipotesis Uji Levene's Test adalah:

$\mathrm{H}_{0}$ : Varians kedua data homogen

$\mathrm{H}_{\mathrm{a}}$ : Varians kedua data tidak homogen

\section{Uji Hipotesis}

Untuk hipotesis kemampuan berpikir kreatif matematis peserta didik sebelum dan sesudah menggunakan pembelajaran dengan Model PBL maka diuji dengan menggunakan Independent Sample t test. Sebelum dilakukan uji t test (Independent Sample t test) dilakukan uji kesamaan varian dengan F test (Levene's Test), artinya jika varian sama, maka penggunaan Equel Variances Assumed (diasumsikan varian sama) dan jika varian berbeda menggunakan Equel Variances Not Assumed (diasumsikan varian berbeda). Uji hipotesis dilakukan menggunakan SPSS dengan kriteria pengujian adalah apabila probabilitas Asymp. Sig (sig 2tailed) $\leq 0,05(\alpha)$.

Hipotesis statistik yang akan diuji bersifat satu-arah adalah:

Keterangan :

$$
\begin{aligned}
& \text { Ho: } \boldsymbol{\mu}_{1}=\boldsymbol{\mu}_{2} \\
& \mathrm{H}_{\mathrm{a}}: \boldsymbol{\mu}_{1}>\boldsymbol{\mu}_{2} \quad \text { (Walpole, 2005) }
\end{aligned}
$$

$\boldsymbol{\mu}_{\mathbf{1}}=$ rata-rata kemampuan berpikir kreatif matematis diberi model pembelajaran Problem Based Learning berbantuan GeoGebra.

$\boldsymbol{\mu}_{2}=$ rata-rata kemampuan berpikir kreatif matematis diberi pendekatan saintifik. 


\section{HASIL DAN PEMBAHASAN}

Data yang dikumpulkan dalam penelitian ini berupa data kemampuan berpikir kreatif matematis siswa yang diperoleh dengan menggunakan instrumen tes yang berupa lembaran tes pretest dan posttest.

Statistika deskriptif merupakan statistika yang digunakan untuk menganalisis data yang telah diperoleh dari penelitian. Data yang diperoleh dan dianalisis dalam penelitian ini meliputi skor pretest dan posttest yang diberikan kepada 62 siswa yang terdiri atas 31 siswa pada kelas eksperimen dan 31 siswa pada kelas kontrol.

Berikut ini adalah tabel yang menggambarkan data deskriptif pre-test, post-test dan gain ternormalisasi ( $\mathrm{N}$-gain) kemampuan berpikir kreatif matematis siswa.

\section{Tabel 4. Data Deskriptif Pre-Test, Post-Test dan Gain Ternormalisasi (N-gain)}

\begin{tabular}{cccccccc} 
Kemampuan & Skor & \multicolumn{3}{c}{ Eksperimen } & \multicolumn{3}{c}{ Kontrol } \\
& & $\mathrm{n}$ & $\bar{x}$ & $\mathrm{~s}$ & $\mathrm{n}$ & $\bar{x}$ & $\mathrm{~s}$ \\
Kemampuan & Pretest & 31 & 5,8065 & 3,13496 & 31 & 2,7742 & 1,33441 \\
Berpikir Kreatif & Postes & 31 & 22,4839 & 6,90831 & 31 & 18,0968 & 4,69294 \\
& N-gain & 31 & 0,4078 & 0,15023 & & 0,3467 & 0,10225
\end{tabular}

Skor Maksimum Ideal $=47$

Berdasarkan Tabel 4 di atas, diperoleh rataan pretes kemampuan berpikir kreatif kelas eksperimen dan kontrol adalah 5,8065 dan 2,7742 dari skor maksimum ideal 47. Sedangkan rata-rata skor post test kelas eksperimen dan kelas kontrol adalah 22,4839 dan 18,0968 dari skor maksimum ideal 47. Hal ini menunjukkan bahwa terdapat perbedaan kemampuan kreatif matematis siswa pada kelas eksperimen dan kelas kontrol sebelum dan sesudah mendapatkan pembelajaran. Adapun rata-rata skor post test kelas eksperimen dan kelas kontrol masingmasing mengalami peningkatan, dimana rata-rata post test kelas eksperimen yang memperoleh model pembelajaran PBL berbantuan GeoGebra lebih tinggi daripada post test kelas kontrol yang memperoleh pendekatan saintifik. Untuk lebih jelasnya, Tabel 4.1 di atas dapat dibuat diagram yang membandingkan rata-rata skor pretes ,post test dan n-gain sebagai berikut.

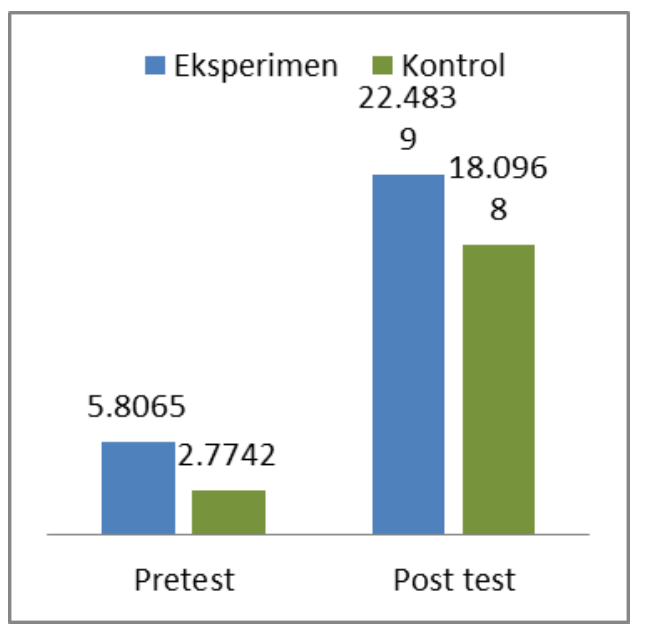

Gambar 1. Rata-rata Skor Pretes, Postes dan Kemampuan Berpikir Kreatif Matematis 


\section{Vol 1, Nomor 1, Mei 2021}

Analisis data N-gain bertujuan untuk melihat peningkatan kemampuan berpikir kreatif matematis siswa yang memperoleh model pembelajaran PBL berbantuan GeoGebra maupun yang memperoleh pendekatan saintifik. Untuk menghitung $N$-gain digunakan skor pre test dan post test dari kelas eksperimen dan kelas kontrol. Hitungan rata-rata skor $n$-Gain kemampuan berpikir kreatif matematis siswa dapat disajikan dalam tabel 4.2 berikut:

\begin{tabular}{ccc} 
Tabel 5 Rata-Rata Skor & $\boldsymbol{N}$-Gain & kemampuan berpikir kreatif matematis \\
\cline { 2 - 2 } Kelas & $\mathbf{N}$-gain & Interpretasi \\
Eksperimen & 0,4078 & Sedang \\
Kontrol & 0,3467 & Rendah \\
\hline
\end{tabular}

Secara lebih jelas perbandingan skor rerata skor pretest, postest kemampuan berpikir kreatif matematis siswa dapat dilihat pada gambar berikut.

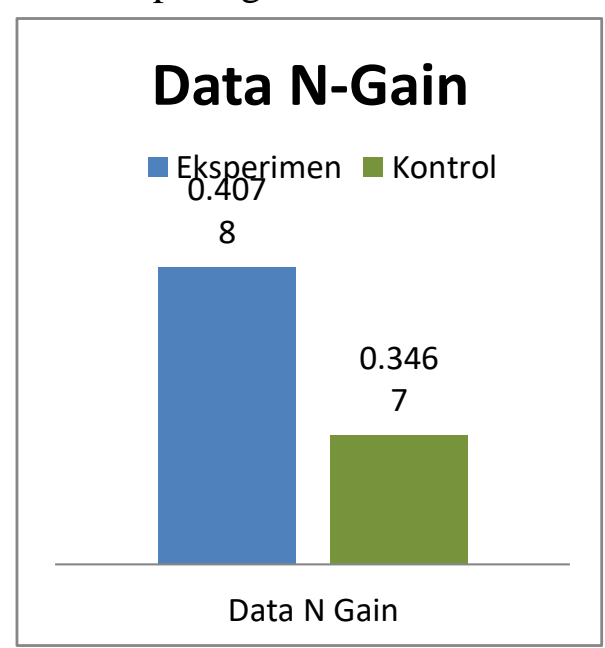

\section{Gambar 2. Rata-rata Skor N-gain Kemampuan Berpikir Kreatif Matematis}

Pada Gambar 4.2 di atas dapat dilihat bahwa rerata n-Gain kemampuan berpikir Kreatif matematis siswa pada kelas eksperimen adalah 0,4078 dengan interpretasi peningkatan sedang, sedangkan rerata $\mathrm{N}$-gain kemampuan berpikir kratif matematis siswa pada kelas kontrol adalah 0,3467 dengan interpretasi peningkatan rendah. Hal ini menunjukkan bahwa peningkatan kemampuan berpikir kratif matematis siswa dengan perlakuan model PBL lebih tinggi daripada peningkatan kemampuan berpikir kratif matematis siswa dengan pendekatan saintifik. Sebelum melakukan pengujian terlebih dahulu harus dilakukan uji prasyarat normalitas dan homogenitas terhadap skor N-gain kedua kelas tersebut.

Tujuan dari penelitian ini adalah untuk mengetahui peningkatan kemampuan berpikir kreatif matematis siswa yang diajarkan melalui model PBL lebih baik daripada siswa yang diajarkan melalui pendekatan saintifik di SMAN 1 Muara Batu. Berdasarkan analisis data skor pretest kemampuan berpikir kreatif matematis siswa antara kelas eksperimen dan kelas kontrol berbeda secara signifikan, hal ini dapat dilihat dari perolehan rerata skor pretest dan postest kelas eksperimen yaitu 5,8065 dan 22,4839, sedangkan perolehan skor pretest dan postest kelas kontrol yaitu 2,7742 dan 18,0968. Dari hasil penilitian yang telah dikemukakan di atas dibandingkan dengan pendekatan saintifik, PBL menunjukkan peran yang berarti dalam meningkatkan kemampuan berpikir kreatif matematis siswa, hal ini 


\section{Vol 1, Nomor 1, Mei 2021}

ditunjukkan dengan adanya perbedaan rerata skor gain kelompok eksperimen dan kontrol setelah diberikan perlakuan. Hasil penelitian menunjukkan bahwa peningkatan kemampuan berpikir kreatif matematis siswa yang berindikator (1) Fluency (Kefasihan). (2) Elaboration (Keterincian). (3) Flexybility (Keluwesan). (4) Originality (Keaslian) yang diajarkan melalui PBL lebih baik daripada siswa yang diajarkan melalui pendekatan saintifik.

Penelitian ini dilaksanakan sebanyak lima kali pertemuan untuk masing-masing kelas, pertemuan satu untuk pretest, tiga pertemuan untuk memberikan pembelajaran pada kelas, dan satu pertemuan untuk postest. Penelitian ini menggunakan dua kelas yang disajikan sebagai sampel penelitian, yaitu XI MIA 2 sebagai kelas eksperimen dan kelas XI MIA 3 sebagai kelas kontrol yang ditetapkan sebelum awal penelitian dilakukan.

Pembelajaran yang diterapkan dalam penelitian ini di kelas eksperimen menggunakan model pembelajaran PBL yang dipadukan dengan aplikasi GeoGebra. Problem Based learning adalah pembelajaran yang dirancang dengan masalah-masalah yang menuntut siswa mendapat pengetahuan yang penting, membuat mereka mahir dalam memecahkan masalah, dan memiliki strategi belajar sendiri serta memiliki kecakapan berpartisipasi dalam tim. Sedangkan aplikasi GeoGebra adalah software matematika dinamis yang dapat digunakan sebagai alat bantu dalam pembelajaran matematika.

Proses pembelajaran di kelas eksperimen yang menggunakan model PBL berbantuan GeoGebra dilakukan selama tiga pertemuan. Pada pertemuan pertama proses pembelajaran dilakukan sesuai dengan langkah-langkah dari model PBL berbantuan GeoGebra dilakukan dengan langkah-langkah (1) Orientasi Siswa kepada masalah, disini peneliti mengajak siswa mengamati (membaca), memahami dan menganalisis masalah kemudian menuliskan informasi yang telah didapat dari masalah tersebut. (2) Mengorganisasi siswa untuk belajar, disini peneliti peneliti meminta siswa membentuk kelompok heterogen dan membagikan LKPD kepada tiap-tiap kelompok. (3) Membimbing penyelidikan individual maupun kelompok, disini peneliti mengajak siswa mendiskusikan proses penyelesaian permasalah yang diberikan dan mengikuti langkah-langkah yang telah diberikan yaitu langkah- langkah mengaplikasikan GeoGebra. (a) Peneliti menginstruksikan siswa membuka file GeoGebra. (b) Pada bagian input/masukan kita ketik fungsi $\mathrm{f}(\mathrm{x})$ nya yaitu dengan cara ketik Integral[fungsi $\mathrm{f}(\mathrm{x})$ ]. (c) Kemudian klik enter, maka akan langsung dapat hasil dari integral yang kita cari yaitu $\mathrm{f}(\mathrm{x})$ beserta grafiknya. (4) Mengembangkan dan menyajikan hasil karya. (5) Menganalisis dan mengevaluasi proses pemecahan masalah.

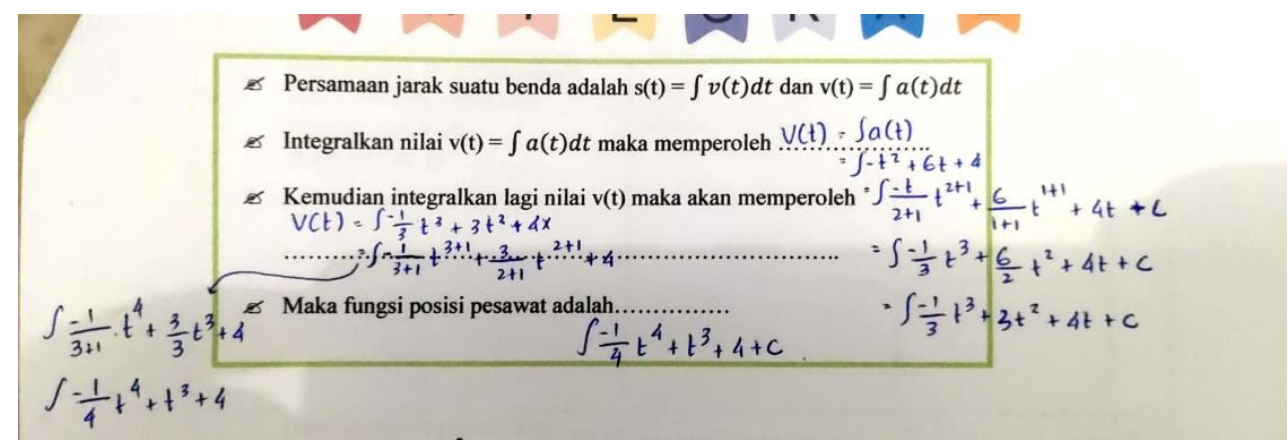

Gambar 3. Jawaban Siswa Kelas Eksperimen

Gambar 4.3 merupakan salah satu jawaban LKPD siswa di kelas eksperimen. Dari jawaban di atas memenuhi indikator kreatif berupa fluency (kefasihan). Indikator kefasihan 
Vol 1, Nomor 1, Mei 2021

dilihat dari kemampuan siswa memberi banyak cara atau gagasan untuk menjawab . terlihat dari jawaban siswa pada kelas eksperimen kemampuan siswa dalam mencetuskan banyak gagasan atau penyelesaian masalah dan mengembangkan suatu gagasan sehingga menjadi lebih menarik.

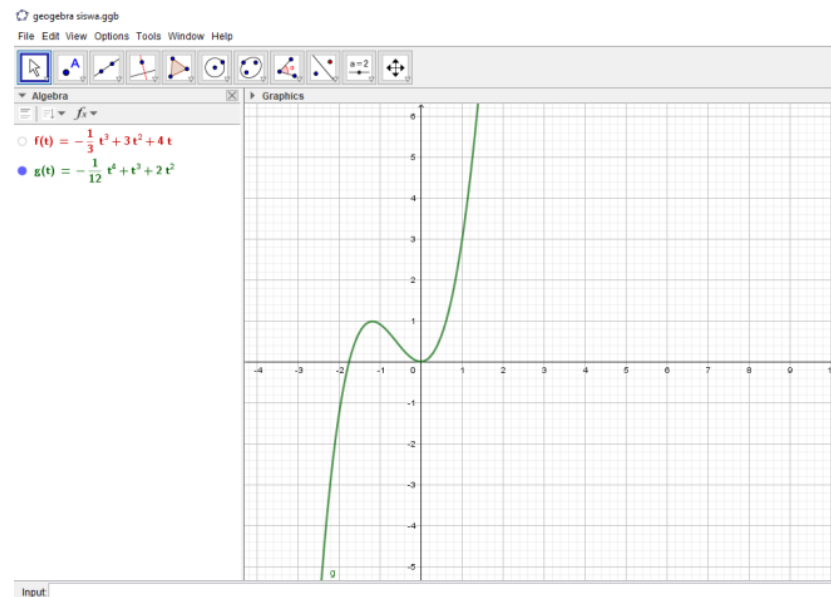

\section{Gambar 4. Jawaban Siswa Eksperimen Menggunakan Geogebra}

Gambar merupakan salah satu jawaban siswa menggunakan aplikasi GeoGebra di kelas eksperimen, dilihat dari pengerjaan siswa pada aplikasi tersebut memenuhi indikator fluency (kefasihan). Indikator kefasihan dalam pengerjaan GeoGebra dilihat dari kemampuan siswa dalam pengoprasian aplikasi GeoGebra dengan benar dan pengerjaan yang singkat.

Sedangkan pada kelas kontrol proses pembelajaran juga melangsungkan tiga pertemuan. Proses pembelajaran menggunakan metode ceramah dengan segala aktivitas pembelajaran hanya berpusat dari guru, siswa hanya menyimak dan mendengar penjelasan dari guru saja.

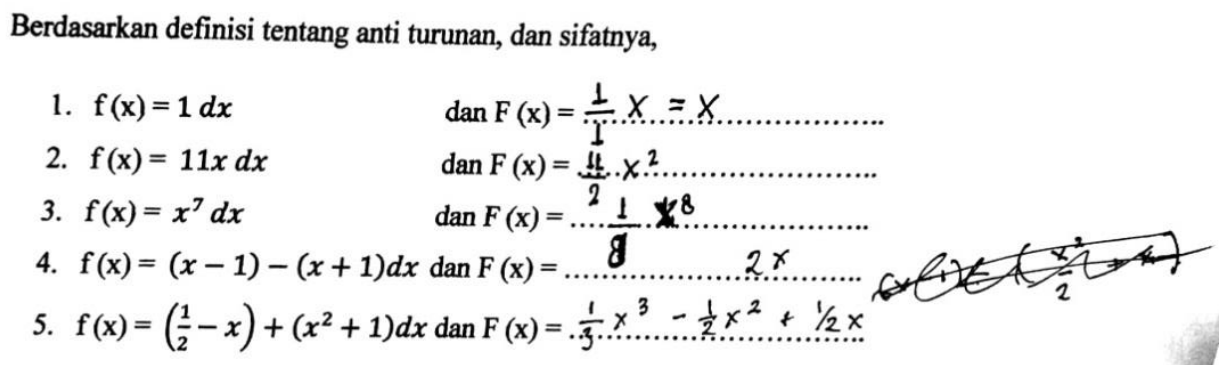

Gambar 5. Jawaban Siswa Kelas Kontrol

\section{Kesimpulan}

Berdasarkan hasil penelitian dapat disimpulkan bahwa, peningkatan kemampuan berpikir kreatif matematis siswa melalui model pembelajaran Problem Based Learning berbantuan GeoGebra lebih baik dari pada kemampuan berpikir kreatif matematis siswa melalui pendekatan saintifik di SMA Negeri 1 Muara Batu. 


\section{DAFTAR PUSTAKA}

Arends, R. I. (2013). Belajar Untuk Mengajar Learning to Teach. Jakarta: Salemba Humanika.

Eggen, P., \& Kauchak. (2012). Strategi dan Model Pembelajaran Mengajarkan Konten dan Keterampilan Berpikir. Jakarta: Indeks.

Hake, R. R. (1998). Interactive-engagement versus traditional methods: A six-thousandstudent survey of mechanics test data for introductory physics courses. American Journal of Physics, 66(1), 64-74. https://doi.org/10.1119/1.18809

I Wayan Eka Aryasuta, I Nengah Suparta, G. S. (2014). Pengaruh model pembelajaran berbasis masalah dengan media pembelajaran berbantuan GeoGebra Terhadap Prestasi Belajar Matematika Siswa Ditinjau Dari Tingkat Ketangguhan Siswa. Jurnal Penelitian Dan Pengajaran Matematika, 3(1).

Meltzer, D. E. (2002). The relationship between mathematics preparation and conceptual learning gains in physics: A possible "hidden variable" in diagnostic pretest scores. American Journal of Physics, 70(12), 1259-1268. https://doi.org/10.1119/1.1514215

Nadeem, M., Assistant, A., \& Lecturer, S. S. (2012). A Comparison of Creative Thinking Abilities of High and Low Achievers Secondary School Students. International Interdisciplinary Journal of Education, 1(1), 3-8.

Rahmadani , A. D. (2017). Meningkatkan Kemampuan Berpikir Kreatif Matematis Siswa SMP Melalui Penerapan Strategi Brain-Based Learning Berbantuan GeoGebra. Skripsi. Bandung: Universitas Pendidikan Indonesia.

Selvy, Y. (2018). Penerapan Model Pembelajaran Based Learning (PBL) Berbantuan Software Geogebra Untuk Meningkatkan Kemampuan Berpikir Kreatif Matematis dan Motivasi Siswa SMA. Skripsi. Banda Aceh: Universitas Syiah Kuala.

Sugiyono. (2010). Metode Penelitian Kuantitatif dan R\&D. Bandung: Alfabeta.

Supinah, \& Sutanti. (2010). Pembelajaran Matematika di SD. Yogyakarta: PPPPTK Matematika.

Walpole, R. E. (2005). Pengantar Statistika. Jakarta: Gramedia Pustaka Utama. 